\title{
Chemometric evaluation of enzymatic hydrolysis in the production of fish protein hydrolysates with acetylcholinesterase inhibitory activity
}

\author{
Thaysa Fernandes Moya Moreira ${ }^{a, *}$, Luiz Gustavo Antunes Pessoa ${ }^{\mathrm{b}}$, \\ Flavio Augusto Vicente Seixas ${ }^{b}$, Rafael Porto Ineu ${ }^{c}$, Odinei Hess Gonçalves ${ }^{c, d}$, Fernanda \\ Vitória Leimann ${ }^{\mathrm{c}, \mathrm{d}, *}$, Ricardo Pereira Ribeiro ${ }^{\text {a, }}$ \\ ${ }^{\text {a }}$ Post-Graduation Program of Food Science (PPC), Department of Animal Science, State University of Maringá, Av. Colombo, 5790, CEP 87030-121, Maringá, PR, \\ Brazil \\ ${ }^{\mathrm{b}}$ Department of Technology, State University of Maringá, Av. Ângelo Moreira da Fonseca, 1800, CEP 87506-360, Umuarama, PR, Brazil \\ ${ }^{\mathrm{c}}$ Post-Graduation Program of Food Technology (PPGTA), Federal University of Technology - Paraná - UTFPR, Campus Campo Mourão, via Rosalina Maria dos Santos, \\ 1233, CEP 87301-899, Caixa Postal: 271, Campo Mourão, PR, Brazil \\ d Centro de Investigação de Montanha (CIMO), Instituto Politécnico de Bragança, Campus de Santa Apolónia, 5300-253, Bragança, Portugal
}

\section{A R T I C L E I N F O}

\section{Keywords:}

Fish protein hydrolysates

Enzymatic hydrolysis

Experimental design

Acetylcholinesterase

\begin{abstract}
A B S T R A C T
Fish protein hydrolysates (FPH) obtained from industrial processing residues are sources of bioactive peptides. The enzymatic hydrolysis process is essential in obtaining specific bioactivities such as inhibition of the enzyme acetylcholinesterase (AChE). In this study the effect of different hydrolysis conditions on the properties of FPH to inhibit the enzyme acetylcholinesterase. A chemometric evaluation, based on a central composite rotatable design and principal component analysis, was applied to select hydrolysis conditions with best yield, degree of hydrolysis and acetylcholinesterase inhibition. Experimental design results for AChE inhibition were between 10.51 and $40.45 \%\left(20,30\right.$ and $50 \mathrm{mg} \cdot \mathrm{mL}^{-1}$ of $\left.\mathrm{FPH}\right)$, and three hydrolysis conditions were selected based on PCA evaluation. The amino acids profile, FTIR and AChE inhibition kinetics were evaluated. Results showed a mixed type of inhibition behavior and, the docking molecular analyzes suggest that the inhibition AChE occurred due to the basic amino acids, mainly by arginine.
\end{abstract}

\section{Introduction}

The 2019 estimate for global fish production is an increasingly stable growth, totaling 177.8 million tons. Despite this, among this scenario, the aquaculture sector stands out for presenting an increase of around $3.9 \%$ when producing in nurseries, mainly, salmon, tilapia and pangasius species (Food and Agriculture Organization [FAO], 2020). With this increase in processing, concerns about the generation and reuse of waste are also intensified. In aquaculture farms, the by-products generated in the filleting process, such as heads, trimmings, frames and viscera, are considered the new sources of waste and constitute about $60-70 \%$ of the weight of live fish (Ananey-Obiri \& Tahergorabi, 2018; Vázquez et al., 2020). According to Food and Agriculture Organization (FAO, 2016), the decrease in post-catch losses could add 15 million tons of fish to the food chain.

An alternative to reduce these losses may be the re-use of filleting byproducts for the production of high aggregate value products such as fish protein hydrolysates (FPH), which represent peptides and short chain amino acids resulting from partial hydrolysis (Chalamaiah et al., 2012). FPH are known as the most important sources of bioactive proteins and peptides, showing potential in several studies for presenting antioxidant activities (Hemker et al., 2020; Wong et al., 2019); antihypertensive (Vázquez et al., 2020); angiotensin converting enzyme (ACE) inhibitory agent (Nasir \& Sarbon, 2019); anti-inflammatory (Ahn et al., 2015) and antimicrobial (Lima et al., 2019).

There has been an effort in the last decades to find compounds from natural sources that could act as acetylcholinesterase (AChE) inhibitors. The main reason is that there is evidence that the damage to the cholinergic system is closely related to brain dysfunctions such as Parkinson's disease (Ventura et al., 2010; Grella Miranda et al., 2020; Prasasty et al., 2018). This relationship is recognized for Alzheimer's disease (AD), in which the loss of cholinergic function contributes to the decrease in cognitive activity associated with AD (Tan et al., 2018). To our knowledge, FPH was not yet evaluated for obtained from by-

\footnotetext{
* Corresponding authors.

E-mail addresses: thaysa.moya@gmail.com (T.F.M. Moreira), fernandaleimann@utfpr.edu.br (F.V. Leimann), rpribeiro@uem.br (R.P. Ribeiro).
} 
products and little explored for food-derived peptides is the inhibitory activity of acetylcholinesterase. The possibility of obtaining low cost, low toxicity, natural substances that could act in the inhibitory mechanism of acetylcholinesterase could be of great importance to the food industry.

The objective of this study was to select the best conditions for enzymatic hydrolysis to relate it to its bioactive capacity to inhibit the acetylcholinesterase enzyme, as well as evaluating changes in the protein structure responsible for this property.

\section{Material and methods}

\subsection{Materials}

Nile Tilapia (Oreochromis niloticus) waste (bones, carcass and fins) were obtained in a local market in 2019 (Campo Mourão, state of Paraná, Brazil). The enzymatic hydrolysis was started using alcalase $2.4 \mathrm{~L}$ enzyme ( $\geq 2.4 \mathrm{U} / \mathrm{g}$, P4860, Sigma-Aldrich). The concentration of soluble proteins was determined by bovine albumin standard curve (A7030, Sigma-Aldrich). The reagents used for the acetylcholinesterase (AChE) activity were trihydroxymethyl aminomethane (Tris-HCl, Dinâmica), acetylcholinesterase enzyme from Electrophorus electricus (electric eel, Sigma-Aldrich), 5,5-dithiobis (2-nitrobenzoic acid) (DTNB, 98\%, SigmaAldrich), acetylthiocholine iodide (ASCh) (Sigma-Aldrich, 99\%), for the preparation of potassium phosphate buffer (TFK) were used monobasic potassium phosphate (Dinâmica) and dibasic potassium phosphate (Neon). To identify and quantify the aminoacids (Asp, Glu, Ser, Gly, His, Arg, Thr, Ala, Pro, Tyr, Val, Met, Cys, Ile, Leu, Phe and Lys) were used an external standard (Standard H, Pierce, P/N 20088), and an internal standard (alpha-aminobutyric acid - Aldrich, Milwawkee-USA).

\subsection{Treatment of Nile Tilapia waste}

Fish waste (bones, carcass and fins) were separated from the carcass, ground, homogenized and dried at $180{ }^{\circ} \mathrm{C}$ in a convection oven for one hour to remove the excess of water. After this period, the waste was stored at $-80{ }^{\circ} \mathrm{C}$ until its use for the production of fish protein hydrolysates (FPH).

\subsection{Proximate composition of Nile Tilapia waste}

After drying as described above, the proximate composition of the fish waste was carried out as described by Association of Official Agricultural Chemists (AOAC, 2005). The gravimetric method was used to determine the moisture at $105{ }^{\circ} \mathrm{C}$ until obtaining constant weight. In order to evaluate the ash content, the fish waste was incinerated in muffle at $550{ }^{\circ} \mathrm{C}$. The lipids were determined by Bligh \& Dyer method and the protein content was obtained by MicroKjeldahl method with correction nitrogen-to-protein factor of 6.25.

\subsection{Obtaining of fish protein hydolysates (FPH)}

The production of protein hydrolysates was performed according to Alvares et al. (2018), with some adaptations. Briefly, fish waste was partially thawed at $10^{\circ} \mathrm{C}$ for $8 \mathrm{~h}$, solubilized in distilled water $(1: 2, \mathrm{wt}$ : v), the $\mathrm{pH}$ adjusted with $\mathrm{NaOH} 1 \mathrm{M}$ or $\mathrm{HCl} 0.1 \mathrm{M}(7.2-8.8)$, after that the alcalase enzyme was added $(0.53-1.9,[\mathrm{E}: \mathrm{S}] \% \mathrm{v} / \mathrm{wt})$, the temperature was adjusted $\left(42-58{ }^{\circ} \mathrm{C}\right)$ and the mixture was kept under agitation for $120 \mathrm{~min}$, as per experimental design. The enzymatic reaction was ended by heating the mixture at $90{ }^{\circ} \mathrm{C}$ for $15 \mathrm{~min}$. After that, the mixture was cooled and centrifuged at $6,000 \mathrm{rpm}(3684 \mathrm{~g}$ ) for $20 \mathrm{~min}$. The supernatant was collected and filtered with a $0.45 \mu \mathrm{m}$ cellulose acetate membrane filter (11106-47-N, Sartorius) with the aid of a vacuum pump. The filtrate FPH was frozen in ultra-freezer $\left(-80^{\circ} \mathrm{C}\right)$ for $24 \mathrm{~h}$ and freeze-dried.

\subsection{Degree of hydrolysis $(\mathrm{DH})$}

The FPH samples degree of hydrolysis (DH) was determined by modifying the methodologies described by Hoyle and Merrltt (1994) and Baek and Cadwallader (1995). After hydrolysis, $6 \mathrm{~mL}$ were removed from the hydrolysates and inactivated with $4 \mathrm{~mL}$ trichloroacetic acid (TCA) $6.25 \%$, followed by rest for $15 \mathrm{~min}$ and centrifuged at $6,000 \mathrm{rpm}$ for $20 \mathrm{~min}$. The concentration of soluble and proteins was determined by the modified Lowry method (Lowry et al., 1951). For this, a bovine albumin standard curve $\left(y=16.541 x+0.0238 ; \mathrm{R}^{2}=0.9915\right)$ was obtained to compare absorbance readings at $750 \mathrm{~nm}$ that were performed in UV-Vis spectrophotometer (Ocean Optics USB650UV, USA). The degree of hydrolysis (GH) was calculated by Equation (1).

$\mathrm{DH}(\%)=\left(\frac{6.25 \backslash \% \mathrm{TCA} \text { solubleproteininthesample }(\mathrm{mg})}{\text { totalproteininthesample }(\mathrm{mg})}\right) \times 100 \%$

Total protein $(29.01 \%)$ was determined by the MicroKjeldahl method (AOAC, 2005) and the conversion factor used was 6.25.

\subsection{Yield}

After the thermal inactivation of the enzymatic hydrolysis samples were cooled at room temperature. The samples were weighed and then fractionated into a centrifuge under conditions of 6,000 rpm for $20 \mathrm{~min}$, in which the aqueous fraction (containing the protein hydrolysates) was transferred, weighed, and stored at $-80^{\circ} \mathrm{C}$. The yield was calculated according to Equation (2).

Yield $(\%)=\frac{\text { aqueousfractionweight }(g)}{\text { hydrolyzedweightbeforefractionation }(g)} \times 100 \%$

\subsection{AChE activity assay}

The AChE activity of FPH was measured as described by Ellman et al. (1961). The analysis was performed in duplicate using in the reaction medium: $90 \mu \mathrm{L}$ of potassium phosphate buffer (TFK, $50 \mathrm{mM}, \mathrm{pH} 7.5$ ), 45 $\mu \mathrm{L}$ of water, $15 \mu \mathrm{L}$ of the enzyme from electric eel $\left(1.25 \mathrm{U}_{\mathrm{mL}}^{-1}\right.$ in Tris$\mathrm{HCl}$ buffer (20 mM, pH 7.5)) and $10 \mu \mathrm{L}$ of FPH (at final concentrations of 20,30 , and $50 \mathrm{mg} \cdot \mathrm{mL}^{-1}$ ) in addition to control (without addition of FPH). The medium was incubated at $25^{\circ} \mathrm{C}$ for $10 \mathrm{~min}$ and then $20 \mu \mathrm{L}$ of DTNB $(2 \mathrm{mM})$ and $20 \mu \mathrm{L}$ of acetylthiocholine iodide (ASCh, $0.8 \mathrm{mM}$ ) were added to AChE test in the dark. Reading was performed every minute (for $4 \mathrm{~min}$ ) in a plate reader (Thermo-Plate Reader) at a wavelength of $405 \mathrm{~nm}$. The experiment was performed in quadruplicate. The inhibition rate was determined using Equation (3), where 13.6 is the molar extinction coefficient, 0.01 is the volume of FPH solution and $\Delta$ absorbance is the absorbance variation per minute. The enzymatic activity was expressed in percentage of activity relative to the control group $(100 \%)$.

Reactionrate $\left(\frac{\mathrm{mol}}{\text { L.h }}\right)=\frac{\Delta \text { absorbance }}{13.6 \times 0.01}$

\subsection{Experimental design}

The FPH were obtained according to the experimental conditions determined by a central composite rotatable design (CCRD) generated by the software Statistica 7.1 (StatSoft Incorporation, Tulsa, OK). The objective was the evaluate the influence of experimental conditions used to obtain the FPH on its inhibitory action and other properties. Seventeen experimental points including 8 factorial, 6 axial and 3 replicates at the central point (Table 1 ) were used. The selected dependent variables $\left(\mathrm{X}_{1}, \mathrm{X}_{2}\right.$ and $\left.\mathrm{X}_{3}\right)$ were:

$$
\begin{aligned}
& \mathrm{X}_{1}=\text { Temperature }\left(\mathrm{T},{ }^{\circ} \mathrm{C}\right) \\
& \mathrm{X}_{2}=\mathrm{pH}
\end{aligned}
$$


Table 1

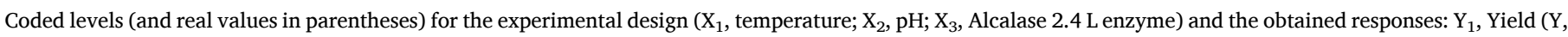
\%); $\mathrm{Y}_{2}$, degree hydrolysis (DH, \%); $\mathrm{Y}_{3}, \mathrm{Y}_{4}$ and $\mathrm{Y}_{5}$, AChE activity inhibition by 20 (AChE 20), 30 (AChE 30) and 50 (AChE 50) mg.mL ${ }^{-1}$, respectively.

\begin{tabular}{|c|c|c|c|c|c|c|c|c|}
\hline \multirow[t]{4}{*}{ run $\mathrm{n}^{\circ}$} & \multicolumn{3}{|c|}{ coded levels (real values) } & \multicolumn{5}{|c|}{ responses } \\
\hline & \multirow[t]{3}{*}{$\mathrm{X}_{1} \mathrm{~T}\left({ }^{\circ} \mathrm{C}\right)$} & \multirow[t]{3}{*}{$\mathrm{X}_{2} \mathrm{pH}$} & \multirow[t]{3}{*}{$\mathrm{X}_{3} \mathrm{E}(\%)$} & \multirow{3}{*}{$\frac{Y_{1}}{Y(\%)}$} & \multirow{3}{*}{$\frac{\mathrm{Y}_{2}}{\mathrm{DH}(\%)}$} & $\mathrm{Y}_{3}$ & $\mathrm{Y}_{4}$ & $\mathrm{Y}_{5}$ \\
\hline & & & & & & \multicolumn{3}{|c|}{ AChE activity inhibition (\%) (mg.mL $\left.{ }^{-1}\right)$} \\
\hline & & & & & & AChE 20 & AChE 30 & AChE 50 \\
\hline 1 & $-1(45)$ & $-1(7.5)$ & $-1(0.8)$ & 76.49 & $14.05 \pm 0.11$ & $20.93 \pm 4.72$ & $22.00 \pm 4.44$ & $29.30 \pm 3.48$ \\
\hline 2 & $1(55)$ & $-1(7.5)$ & $-1(0.8)$ & 86.33 & $18.54 \pm 2.15$ & $21.53 \pm 2.66$ & $26.19 \pm 1.41$ & $40.45 \pm 3.63$ \\
\hline 3 & $-1(45)$ & $1(8.5)$ & $-1(0.8)$ & 83.66 & $13.74 \pm 0.61$ & $15.77 \pm 0.96$ & $22.98 \pm 2.41$ & $37.00 \pm 1.75$ \\
\hline 4 & $1(55)$ & $1(8.5)$ & $-1(0.8)$ & 74.75 & $16.22 \pm 0.53$ & $19.98 \pm 1.83$ & $20.63 \pm 2.05$ & $34.64 \pm 1.56$ \\
\hline 5 & $-1(45)$ & $-1(7.5)$ & $1(1.6)$ & 85.83 & $15.20 \pm 0.27$ & $22.21 \pm 1.17$ & $26.70 \pm 2.31$ & $30.75 \pm 2.57$ \\
\hline 6 & $1(55)$ & $-1(7.5)$ & $1(1.6)$ & 82.48 & $23.37 \pm 1.17$ & $17.85 \pm 2.24$ & $22.49 \pm 1.48$ & $31.69 \pm 2.33$ \\
\hline 7 & $-1(45)$ & $1(8.5)$ & $1(1.6)$ & 81.99 & $18.06 \pm 0.61$ & $10.51 \pm 2.04$ & $13.71 \pm 1.03$ & $18.11 \pm 1.07$ \\
\hline 8 & $1(55)$ & $1(8.5)$ & $1(1.6)$ & 88.48 & $18.98 \pm 0.58$ & $17.54 \pm 1.86$ & $32.94 \pm 3.34$ & $34.45 \pm 2.52$ \\
\hline 9 & $0(50)$ & $0(8)$ & $0(1.2)$ & 76.46 & $51.31 \pm 2.57$ & $14.30 \pm 2.70$ & $22.36 \pm 2.49$ & $35.40 \pm 3.62$ \\
\hline 10 & $0(50)$ & $0(8)$ & $0(1.2)$ & 77.96 & $50.49 \pm 8.07$ & $22.34 \pm 2.15$ & $27.76 \pm 1.86$ & $37.64 \pm 1.08$ \\
\hline 11 & $0(50)$ & $0(8)$ & $0(1.2)$ & 79.65 & $47.41 \pm 1.70$ & $20.96 \pm 0.62$ & $27.79 \pm 2.82$ & $36.38 \pm 2.49$ \\
\hline 12 & $-1.68(42)$ & $0(8)$ & $0(1.2)$ & 79.73 & $48.80 \pm 3.09$ & $14.53 \pm 3.24$ & $21.27 \pm 3.24$ & $29.60 \pm 1.61$ \\
\hline 13 & $1.68(58)$ & $0(8)$ & $0(1.2)$ & 87.14 & $63.42 \pm 3.01$ & $20.68 \pm 1.88$ & $21.22 \pm 2.39$ & $33.25 \pm 0.50$ \\
\hline 14 & $0(50)$ & $-1.68(7.2)$ & $0(1.2)$ & 75.43 & $54.16 \pm 0.72$ & $12.15 \pm 4.47$ & $17.96 \pm 4.46$ & $30.94 \pm 5.49$ \\
\hline 15 & $0(50)$ & $1.68(8.8)$ & $0(1.2)$ & 78.41 & $64.40 \pm 1.42$ & $17.49 \pm 2.51$ & $27.53 \pm 2.76$ & $32.57 \pm 4.58$ \\
\hline 16 & $0(50)$ & $0(8)$ & $-1.68(0.53)$ & 73.25 & $59.52 \pm 2.68$ & $16.64 \pm 2.06$ & $22.35 \pm 1.37$ & $31.54 \pm 1.61$ \\
\hline 17 & $0(50)$ & $0(8)$ & $1.68(1.9)$ & 77.70 & $64.33 \pm 2.14$ & $13.65 \pm 0.81$ & $19.97 \pm 1.54$ & $31.80 \pm 1.57$ \\
\hline
\end{tabular}

$\mathrm{X}_{3}=$ Enzyme, proportion to the substrate (E, [E:S] \%)

The analytical range was determined based on preliminary experiments and literature reports (Halim et al., 2016). The responses evaluated from the proposed experimental design were:

$$
\begin{aligned}
& \mathrm{Y}_{1}=\text { yield }(\mathrm{Y}, \%) \\
& \mathrm{Y}_{2}=\text { degree of hydrolysis }(\mathrm{DH}, \%) \\
& \left.\mathrm{Y}_{3}=\mathrm{AChE} \text { activity inhibition (AChE } 20 \mathrm{mg} \cdot \mathrm{mL}^{-1}, \%\right) \\
& \left.\mathrm{Y}_{4}=\text { AChE activity inhibition (AChE } 30 \mathrm{mg} \cdot \mathrm{mL}^{-1}, \%\right) \\
& \left.\mathrm{Y}_{5}=\text { AChE activity inhibition (AChE } 50 \mathrm{mg} \cdot \mathrm{mL}^{-1}, \%\right)
\end{aligned}
$$

\subsection{Principal component analysis (PCA)}

A principal component analysis (PCA) was performed using MATLAB R2008b (MathWorks Inc., Natick, MA) in order to explore the relation between the FPH characteristics when obtained under different experimental conditions. The results obtained for Yield $(\mathrm{Y})$, degree of hydrolysis (DH) and inhibition of AChE activity (AChE $20 \mathrm{mg}^{-\mathrm{mL}^{-1}}$, AChE 30 mg. $\mathrm{mL}^{-1}$ and AChE $50 \mathrm{mg} \cdot \mathrm{mL}^{-1}$ ) were placed in columns and the experimental runs were used as rows. Before analysis, each column was mean centered and divided by its variance, resulting in a scaled matrix. The first principal components with eigenvalues higher than 1.0 were used to evaluate the samples distribution in the new projection space.

\subsection{FPH characterization}

For the determination of the molecular characteristics of FPH samples, spectra were collected with an Infrared Spectrophotometer with Fourier Transform (IR AFFINITY-1, Shimadzu), in the range of 4000 to $600 \mathrm{~cm}^{-1}$, using 32 accumulations and $4 \mathrm{~cm}^{-1}$ resolutions. The samples were previously conditioned in a desiccator containing anhydrous calcium chloride $\left(\mathrm{CaCl}_{2}\right)$ for 7 days to remove moisture and spectra bands were normalized for spectrum comparison.

The method for amino acid analysis was based on White et al. (1986) and Hagen et al. (1989). The samples were subjected to acid hydrolysis and pre-column derivatization with phenyl isothiocyanate (PITC). The separation of amino acids was performed by reverse phase liquid chromatography (SHIMADZU Corporation, Tokyo, Japan) equipped with C18 reverse phase column $\left(50^{\circ} \mathrm{C}\right)(\mathrm{LUNA}$ C18, $100 \AA$, $5 \mu \mathrm{m}, 250 \times 4.6$ $\mathrm{mm}$, Phenomenex Inc., Torrance, USA), with DAD detector at $254 \mathrm{~nm}$. The mobile phase used was a gradient composed by (A) Sodium acetate buffer $94 \%(0.036 \mathrm{M}, \mathrm{pH} 6.4)+5.7 \%$ acetonitrile and (B) Acetonitrile $40 \%$. Gradient time (45 min): In the concentration of the mobile phase A and time (min) respectively $(95 \%, 0-5),(77.5 \%, 5-10),(68 \%, 10-12)$, $(40 \%, 12-20),(0 \%, 20-36),(95 \%, 36-45)$, and flow rate of $1 \mathrm{~mL} \mathrm{~min}^{-1}$, volume injected: $50 \mu \mathrm{L}$.

\subsection{AChE reaction kinetics}

Kinetics parameter determination was carried out using five acetylthiocholine iodide final concentrations $(0.8,0.6,0.4,0.2,0.1$, and 0 $\mathrm{mM})$ and three concentrations $\left(20 \mathrm{mg} \cdot \mathrm{mL}^{-1}, 30 \mathrm{mg} \cdot \mathrm{mL}^{-1}\right.$ and $50 \mathrm{mg}$. $\mathrm{mL}^{-1}$ ) from the FPH assays (2,12 and 14). The inhibition constant of the enzyme substrate inhibitor complex (Ki) was obtained through the Lineweaver- Burk methodology using Prism GraphPad 5.0 software.

\subsection{Molecular docking studies}

Molecular docking was carried out in order to give insight on the possible interaction site responsible for the enzyme inhibition. The crystallographic structure of choline-linked acetylcholinesterase (pdbid: 2 ha3) with $2.25 \AA$ resolution was chosen for docking studies. The library with the three-dimensional structure of amino acids present in the FPH was obtained as the *.sdf. The programs and protocols used in the docking simulations were defined by redocking the choline ligand (pubchem cid: 305 ). The protocols were considered validated when the root mean square deviation (rmsd) from the overlapping choline ligand in the crystallographic complex was less than $2.0 \AA$. The program Autodock-4.2.3 (Morris et al., 2009) used the graphical interface Pyrx0.9.8 (Dallakyan \& Olson, 2015) and had as protocol the standard algorithm for search and ranking, number of runs $=50$, energy adjusted for Medium, 30-dimensional search box on the three axes and centered on 26,20 and 14 on the $\times, y$ and $z$ axes respectively.

The Gold-2020.2 program (Jones et al., 1997) used the Goldscore search method with $200 \%$ efficiency, a search radius of $8 \AA$ centered on coordinates 26,20 and 14 , on the $\mathrm{x}, \mathrm{y}$ and $\mathrm{z}$ axes respectively. The water molecules present in the structure were kept in the simulations. Due to the different ranking methods used by each program, Equation (4) was applied to the mean scores provided by the programs to select the most likely ligand to bind to AChE.

Meanrelativescore $=\frac{1}{2}\left(\frac{\text { Gold }_{\text {Gold }}}{\max }+\frac{\text { Autodock }_{\text {Autodock }}}{\max }\right)$ 
where Gold represents the score provided by the Gold program for each ligand and Gold $\mathrm{max}_{\text {ax }}$ the score of the highest rated ligand. Same goes for t18he Autodock variables.

\section{Results and discussion}

\subsection{Proximate composition of Nile Tilapia waste}

The proximate composition of the Nile Tilapia waste (Table S1, Supplementary Material) presented compatible values to those reported in the literature. These proportions of the proximate composition may vary according to the residues used for processing. The Nile Tilapia byproducts used by Silva et al. (2014) for the production of FPH showed $42.3 \%$ protein while the by-products used by Roslan et al. (2014) showed $14.6 \%$. Therefore, the proportion of protein $(29.01 \%)$ obtained this work enables its use to produce protein hydrolysates and justifies the importance of the waste reusing.

\subsection{Experimental design and principal component analysis}

Experimental conditions used in the CCRD, as well as the experimental results for the five evaluated responses o FPH production, are presented in Table 1.

The response values ranged between 73.25 and $88.48 \%$ for yield; $13.74-64.40 \%$ for degree of hydrolysis and $10.51-40.45 \%$ for AChE activity inhibition with different concentrations (20, 30 and $50 \mathrm{mg}$. $\mathrm{mL}^{-1}$ ). Nevertheless, the experimental models evaluated, based on the experimental data, did not present significant regression for all evaluated variables (Table S2, Supplementary Material), demonstrating inappropriate for predicting the response in the production of FPH. Therefore, the responses evaluated the experimental design (yield, DH, AChE 20, AChE 30 and AChE 50, Table 1) were submitted to a principal component analysis (PCA) in order to extract more information about the relation between these variables. The obtained PCA graphs are presented in Fig. 1.

The scree plot of eigenvalues, as well as the Mahalanobis distance obtained from the evaluated data set are presented in Figure S1 (Supplementary Material). It was possible to select PCs with eigenvalues higher than 1. Also, the Mahalanobis distance plot did not show any outlier among the evaluated experimental point. Therefore, the loadings obtained to the selected PCs, which show the importance of each PC on each variable, are presented in Figure S2 (Supplementary Material). The variables Enzyme (E) and Yield (Y) were better described by PC2, while the variables Temperature (T), Degree of hydrolysis (DH) and $\mathrm{pH}$ could be represented by PC3 and PC4. Regarding to acetylcholinesterase inhibitions (AChE 20, AChE 30 and AChE 50), all were better represented by PC1.

In Fig. 1 (A), where are presented the scores from PC1 versus PC2 (53.17\% of total variance explained), it is possible to note that all AChE concentrations, as well as the temperature are highly positively correlated, since the corresponding vectors are aligned at the same direction. Thus, it is possible to conclude that the higher hydrolysis temperature, the higher inhibitory action of the final hydrolysate on acetylcholinesterase enzyme. Also, the enzyme concentration and the yield of hydrolysis presented a positive correlation.

For the scores plot related to PC1 versus PC3 (Fig. 1 (B), 49.93\% of total variance explained) the same relation between temperature and AChE inhibition to all considered FPH concentrations was detected. In Fig. 1 (B) it was also verified that the relation between the DH (that represents the cleavage of the peptide bonds), $\mathrm{pH}$ and enzyme concentration is positive with high correlation. Therefore, as high the $\mathrm{pH}$ and enzyme concentration applied, the higher DH obtained for FPH. This result corroborates that described in the literature, in which Mohammad et al. (2015) verified that the higher concentration of the alcalase enzyme was responsible for cleaving more peptide bonds available in the substrate. Cao et al. (2009) noticed a significant interaction between $\mathrm{pH}$ and alcalase $2.4 \mathrm{~L}$ enzyme in the optimization of the shrimp protein hydrolysates, as well, they observed the optimum points with higher $\mathrm{DH}$ at $\mathrm{pH} 8$ and temperature equal to $57^{\circ} \mathrm{C}$. In this sense, when evaluating Fig. 1, could be verified that the experimental points 12,14 and 16 represented the best hydrolysis conditions because they were closer to the positive correlations. At these points, although the mechanisms performed for hydrolysis are different, the DH and AChE activity inhibition results were similar.

Analyzing the scores plot from PC3 versus PC4 (Fig. 1 (C), 27.94\% of total variance explained) the same relation between the degree of hydrolysis, temperature and enzyme concentration can be observed.

Considering the scores plot evaluation, three experimental points to further characterization were selected. The points presenting higher inhibitory action to AChE according to Fig. 1 (A) and (B) were 2, 12, 9 and 10. Among these points, it can be observed that point 2 presented greater inhibition potential than the other experimental conditions. On the other hand, even with reasonable AChE inhibitory results, points 12 and 14 were also selected since they represent results with greater contribution of enzymatic hydrolysis. The selected experimental runs were: 2 (T: $55^{\circ} \mathrm{C}, \mathrm{pH}: 7.5, \mathrm{E}: 0.8 \%$ ), 12 (T: $42{ }^{\circ} \mathrm{C}, \mathrm{pH}: 8, \mathrm{E}: 1.2 \%$ ) and 14 (T: $50{ }^{\circ} \mathrm{C}, \mathrm{pH}: 7.2, \mathrm{E}: 1.2 \%$ ).

\subsection{AChE activity inhibition}

The results of AChE activity inhibition (Table 1 ) ranged from 10.51 $40.45 \%$ at different FPHs concentrations (20, 30 and $50 \mathrm{mg} \cdot \mathrm{mL}^{-1}$ ) obtained by the different hydrolysis conditions. As expected, inhibition
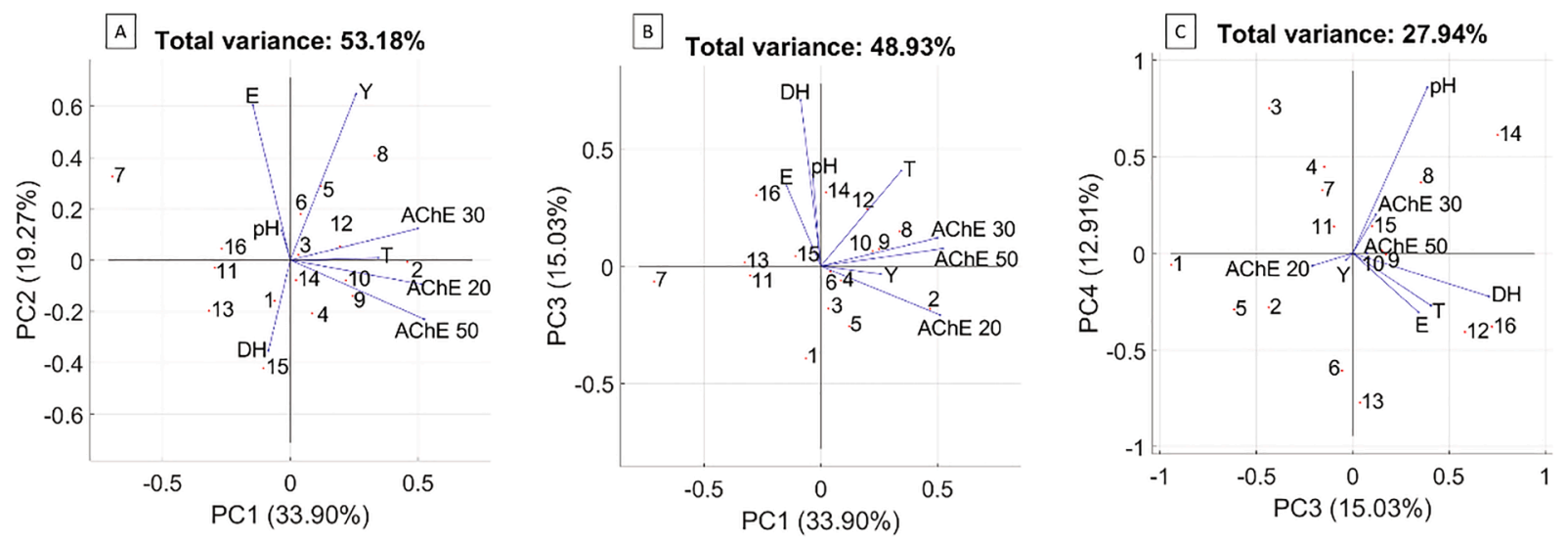

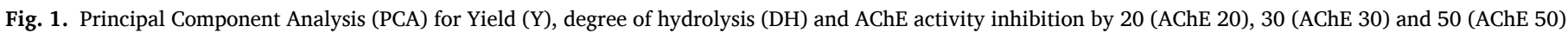
mg.mL ${ }^{-1}$, respectively. PC1 versus PC2 (A), PC1 versus PC3 (B) and PC3 versus PC4 (C). 
results increased with concentration. Also, it could be verified that the evaluated concentrations and their respective inhibitions were adequate as reported by other studies.

Su et al. (2016) evaluated the AChE inhibition by anchovy protein hydrolysates, at higher concentrations when compared to the present study, between 100 and $400 \mathrm{mg} \cdot \mathrm{mL}^{-1}$, which resulted at 10-60\% inhibition. On the other hand, Naik et al. (2020), evaluated the inhibition of mussel by-products hydrolysates at significantly lower concentration than reported in this study $\left(1 \mathrm{mg} \cdot \mathrm{mL}^{-1}\right)$ and obtained similar AChE inhibition (29.59\%). This variation in the hydrolysates' concentration for AChE inhibition may be due to several factors such as enzyme specificity, DH, molecular weight, amino acid sequence, hydrophobicity and peptide loading (Gao, Yu, Shen, Chu, Chen, Fen, Yang, Yuan, McClements, et al., 2021). Malomo and Aluko (2016) indicate that AChE inhibitory activity occurs mainly by the type and sequence of amino acids in the peptide chain. However, the exact mechanism of the FPHs action in the AChE inhibition is not yet fully understood.

In this work, the hydrolysis temperature influenced the AChE activity (Fig. 1 (A)). This may have occurred due to possible changes in the structure, which may result in modifications on peptides and at their amino acids (Zhao et al., 2018). In addition, AChE inhibition was not directly related to peptide size, represented by DH (i.e. the higher the DH the smaller the peptide size), since the FPHs with very different DH values showed close inhibitions. For instance, points 2 and 10 with $\mathrm{DH}$ of $18.54 \%$ and $50.49 \%$ presented AChE inhibition values of $40.45 \%$ and $37.64 \%$, respectively. This feature was also verified by Zent et al. (2021) and Malomo and Aluko (2016) when evaluating protein hydrolysates obtained from plants.

\subsection{FPH characterization}

\subsubsection{Fourier transform infrared spectroscopy (FTIR)}

In Fig. 2 are presented the FTIR spectra of the FPH obtained with experimental points 2,12 and 14 .

FTIR is a method used to evaluate the structure modification of proteins and peptides submitted to enzymatic hydrolysis. This analysis is useful because after cleavage of peptide bonds structural changes can occur and C-terminal carboxylate $\left(\mathrm{COO}^{-}\right)$and $\mathrm{N}$-terminal amino $\left(\mathrm{NH}_{3}{ }^{+}\right)$ groups can be formed, which can be identified in the infrared absorption bands (Böcker et al., 2017). Therefore, the characteristic bands of protein hydrolysates identified in Fig. 2 for all analyzed FPHs were: amide A (3410 and $3293 \mathrm{~cm}^{-1}$ ); amide B $\left(3075 \mathrm{~cm}^{-1}\right)$; amide I $\left(1656 \mathrm{~cm}^{-1}\right.$ ); amide II $\left(1559 \mathrm{~cm}^{-1}\right)$ and amide III $\left(1261 \mathrm{~cm}^{-1}\right)$ (Elavarasan et al., 2016; Noman et al., 2020).

In amide $\mathrm{A}$, the $\mathrm{N}-\mathrm{H}$ stretching vibration was observed for points 12 and 14 at $3410 \mathrm{~cm}^{-1}$ as described in the literature $\left(3400-3440 \mathrm{~cm}^{-1}\right)$. However, for point 2 this position was shifted to a wavenumber of 3293 $\mathrm{cm}^{-1}$, possibly because peptide $\mathrm{O}-\mathrm{H}$ and $\mathrm{N}-\mathrm{H}$ stretching is involved by a hydrogen bond (Elavarasan et al., 2016).

The Amide I band occurs at $1700-1600 \mathrm{~cm}^{-1}$ due to stretching vibrations of $\mathrm{C}=\mathrm{O}$ coupled weakly with $\mathrm{C}-\mathrm{N}$ stretch and $\mathrm{N}-\mathrm{H}$ bending. In this region, there was only one band at $1656 \mathrm{~cm}^{-1}$ for all FPHs, which can be attributed to the existence of $\alpha$-helical structures and/or more complex structures, such as an $\alpha$-helix superimposed on a random coil. Amide II, observed at $1559 \mathrm{~cm}^{-1}$, probably was due to $\mathrm{C}-\mathrm{N}$ stretch along with $\mathrm{N}-\mathrm{H}$ in-plane bending, and, amide III (at $1261 \mathrm{~cm}^{-1}$ ), resulted from $\mathrm{N}-\mathrm{H}$ bending and $\mathrm{C}-\mathrm{N}$ stretching with deformation vibrations of $\mathrm{C}-\mathrm{H}$ and $\mathrm{N}-\mathrm{H}$ (Glassford et al., 2013).

These amides (I, II and III), are related to changes in the secondary structure of proteins (Yang et al., 2020). This is corroborated by the observed amide bands I and II, which presented lower intensity at points 2 and 14 compared to point 12 . Possibly, this decrease in the intensity of the bands occurred due to temperature influencing the enzymatic hydrolysis process by modifying the protein structure (Noman et al., 2020).

In addition, the presence of phosphate, widely found in fish bones, can also be verified in the spectra. The characteristic bands of the $\mathrm{PO}_{4}{ }^{3-}$ group were identified in three regions. The first one is represented by the bands located at $1094 \mathrm{~cm}^{-1}, 1025 \mathrm{~cm}^{-1}$ corresponding to $v 3$ stretching mode and $924 \mathrm{~cm}^{-1}$ associated to $v 1$ stretching mode (Boskey \& Pleshkocamacho, 2007; Nawaz et al., 2020; Pal et al., 2017).

\subsubsection{Amino acid compositions}

The amino acid compositions of FPH (points 2, 12 and 14) are summarized in Table 2.

Amino acids are indicated as one of the key factors in the bioactive capacity of fish hydrolysates (Chalamaiah et al., 2012). Among the nonessential amino acids presented in Table 2, glutamic acid, that has a significant effect on the regulation of the immune system (Rajabzadeh et al., 2017), presented the highest concentration. Fish hydrolysates and peptides possess potent immunological activity in both cultured cells and mice (Gao, Yu, Shen, Chu, Chen, Fen, Yang, Yuan, Mcclements, et al., 2021).

In general, the amino acid profile (Table 2) was similar for the hydrolysates evaluated, indicating that the peptides recovered in the supernatant presented average similarity on amino acid composition. This result was expected since all samples were produced with the same enzyme, which is capable to cleave a broad spectrum of peptide bonds. However, point 2 presented greater amount of total and essential amino acids. In comparison with the hydrolysates of tilapia residues, the values of the amino acids obtained were lower than those found by Silva et al. (2014) and higher than those obtained by Roslan et al. (2014). These differences in amino acid composition may be due to several factors such as raw material, enzyme used and hydrolysis conditions (mainly the combination of time, temperature, $\mathrm{pH}$ and enzyme concentration)

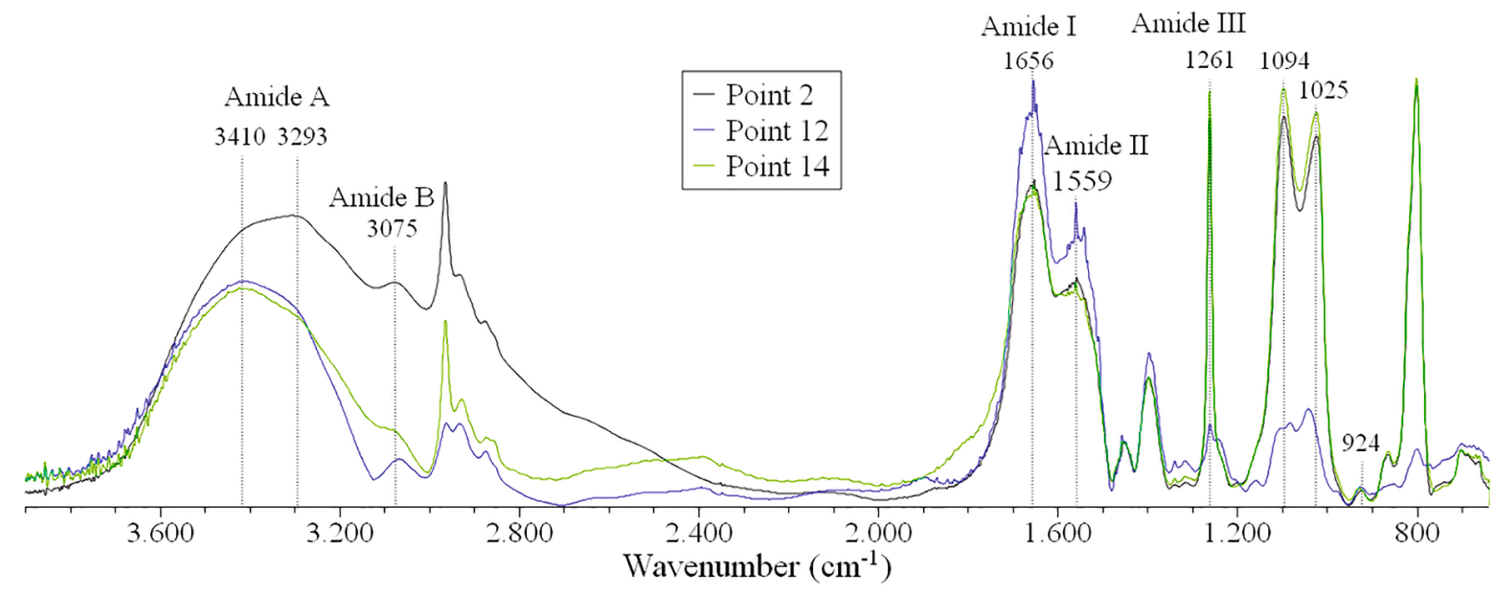

Fig. 2. FTIR spectra of the FPH obtained in Points 2, 12 and 14. 
Table 2

Amino acid compositions of FPH.

\begin{tabular}{lrrr}
\hline \multirow{2}{*}{ Amino acids } & \multicolumn{2}{c}{ P2 } & P14 \\
\cline { 2 - 4 } & \multicolumn{2}{c}{ g/100 g of dry matter } & \\
\hline Aspartic acid (Asp) & 9.45 & 8.71 & 9.12 \\
Glutamic acid (Glu) & 14.83 & 13.56 & 13.94 \\
Serine (Ser) & 3.63 & 3.49 & 3.61 \\
Glycine (Gly) & 9.18 & 9.58 & 8.88 \\
Histidine (His) & 1.89 & 1.87 & 1.93 \\
Arginine (Arg) & 6.32 & 5.55 & 6.29 \\
Threonine (Thr) & 3.62 & 3.33 & 3.55 \\
Alanine (Ala) & 6.82 & 6.83 & 6.58 \\
Proline (Pro) & 5.56 & 5.68 & 5.41 \\
Tyrosine (Tyr) & 2.22 & 1.96 & 2.25 \\
Valine (Val) & 4.10 & 3.92 & 3.97 \\
Methionine (Met) & 2.59 & 2.49 & 2.50 \\
Cysteine (Cys) & 0.49 & 0.43 & 0.37 \\
Isoleucine (Ile) & 3.26 & 3.13 & 3.13 \\
Leucine (Leu) & 6.30 & 6.22 & 6.10 \\
Phenylalanine (Phe) & 2.73 & 2.89 & 2.64 \\
Lysine (Lys) & 7.40 & 7.59 & 7.02 \\
PCAA & 15.61 & 15.01 & 15.24 \\
EAA & 38.21 & 36.99 & 37.13 \\
HAA & 42.76 & 42.70 & 41.46 \\
TAA & 90.39 & 87.23 & 87.29 \\
\hline
\end{tabular}

PCAA (positively charged amino acids): His, Arg and Lys.

EAA (essential amino acids): Ile, Leu, Lys, Met, Phe, Thr, Val, His and Arg HAA (hydrophobic amino acids): Gly, Ala, Pro, Tyr, Met, Val, Phe, Ile, and Leu. TAA (total amino acids).

(Halim et al., 2016).

\subsection{Reaction kinetics}

Fig. 3 presents the Michaelis-Menten substrate competition assays for FPH: points 2 (A), 12 (B) and 14 (C).

The Michaelis-Menten assays demonstrated that the FPH obtained in points 2,12 and 14 were able to decrease the activity of AChE according to the concentration $\left(20,30\right.$ and $50 \mathrm{mg} \cdot \mathrm{mL}^{-1}$ ) when compared to the control $\left(\mathrm{H}_{2} \mathrm{O}\right.$ curve). The Lineweaver-Burk methodology (Figure S3) indicated that all samples presented inhibition of competitive mixedtype, with Ki values of $15.75,11.72$ and $18.45 \mathrm{mg}$ to points 2,12 and 14, respectively. The competitive mixed-type model was also observed by Zhao et al. (2017) (at concentrations of 1-20 mM) and Malomo and Aluko (2019) (at concentrations of $0-0.05 \mathrm{mg} \cdot \mathrm{mL}^{-1}$ ) when evaluating the AChE inhibition kinetics of pure lysine and hemp seed proteinderived peptides, respectively.

\subsubsection{Molecular docking studies}

The structure of AChE enzyme from Mus musculus was used for having tertiary structure similar to that of AChE enzyme from Electrophorus electricus and identity of $60.065 \%$. Similar studies available in the literature also report the use of rat structure in simulations (Grella Miranda et al., 2020).

The visual inspection of the AChE crystallographic structure used in the simulations shows that choline appears bound in two sites of the active site in the enzyme, one at the bottom of the site (further inside the molecule) and another at the entrance of the active site (further on the surface of the molecule). The overlap of other AChE structures in the presence of ligands suggests that the site of choline binding with the greatest affinity should be the one inside the molecule. Binding of the other choline probably occurred due to the high amount of this compound in the structure crystallization solution, resulting in a lower affinity bond at another enzyme site. Thus, the site defined for the fitting of amino acids in the docking simulations was the innermost.

In addition, the structure of Mus musculus AChE, linked to choline (pdbid: 2HA3) was chosen for docking studies because choline has the approximate size of a medium amino acid, which were used in docking
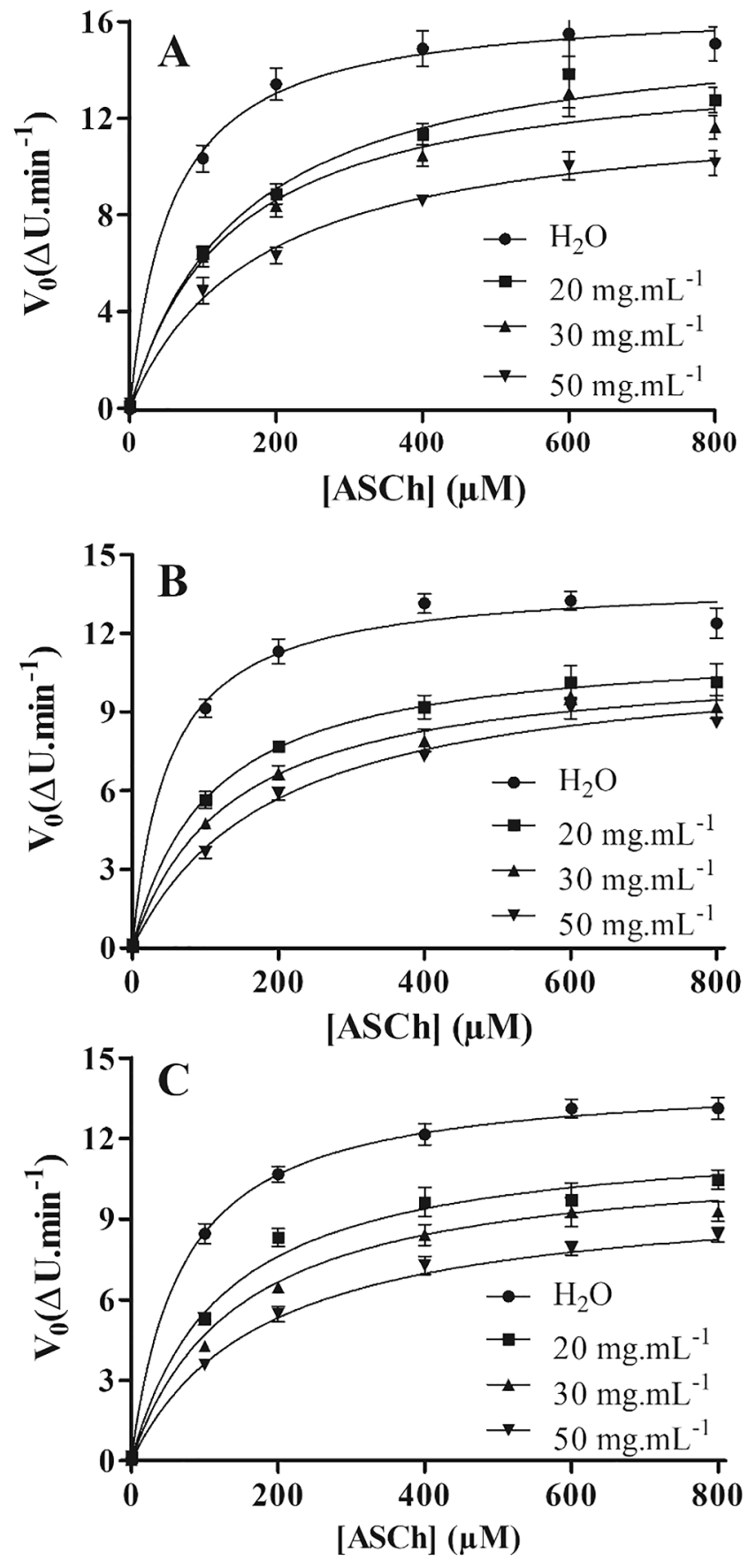

Fig. 3. Michaelis-Menten substrate competition assays for FPH: Points 2 (A), 12 (B) and 14 (C).

simulations.

The result shown in Figure S4 (Supplementary Material) indicates that the amino acid L-arginine (6322) is most likely to bind to AChE, followed by L-cystine (67678), L-tyrosine (6057), L-lysine (5962), Lphenylalanine (6140) and L-histidine (6274). This classification suggests that the basic amino acids prefer to bind to AChE in relation to the others.

Therefore, Fig. 4 (A) and (B) show the overlap of the choline crystallographic ligand used as reference, (C) poses and arginine overlap of docking simulations and, (D) interactions between arginine and residues of the AChE active site.

The validation of the Autodock and Gold programs by redocking shows a good overlap of the choline crystallographic ligand used as a 
$\mathbf{A}$
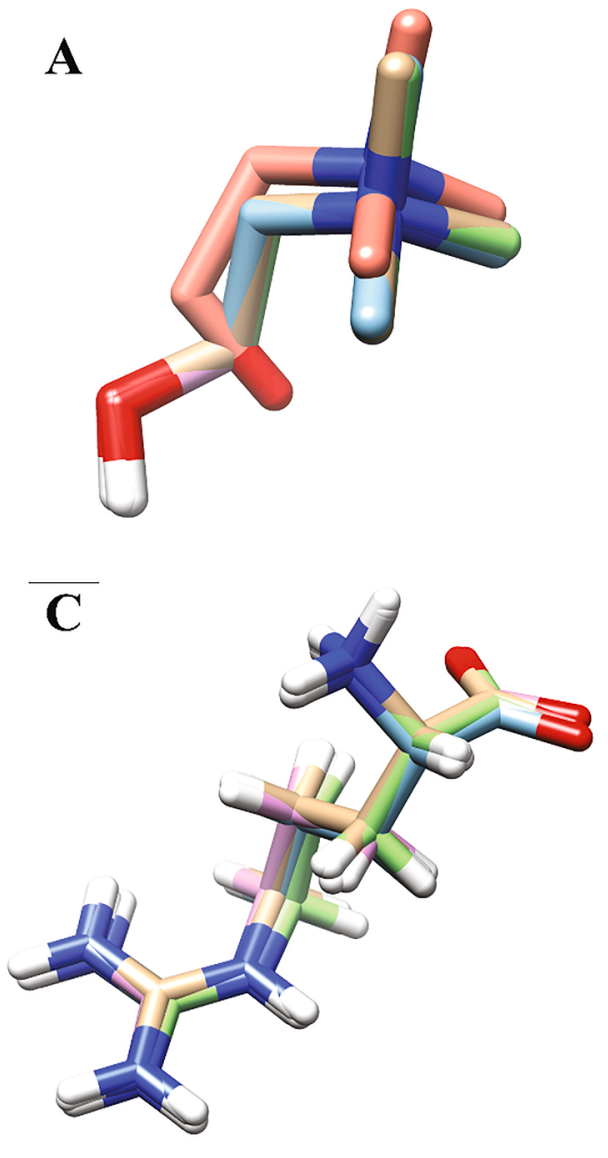

B
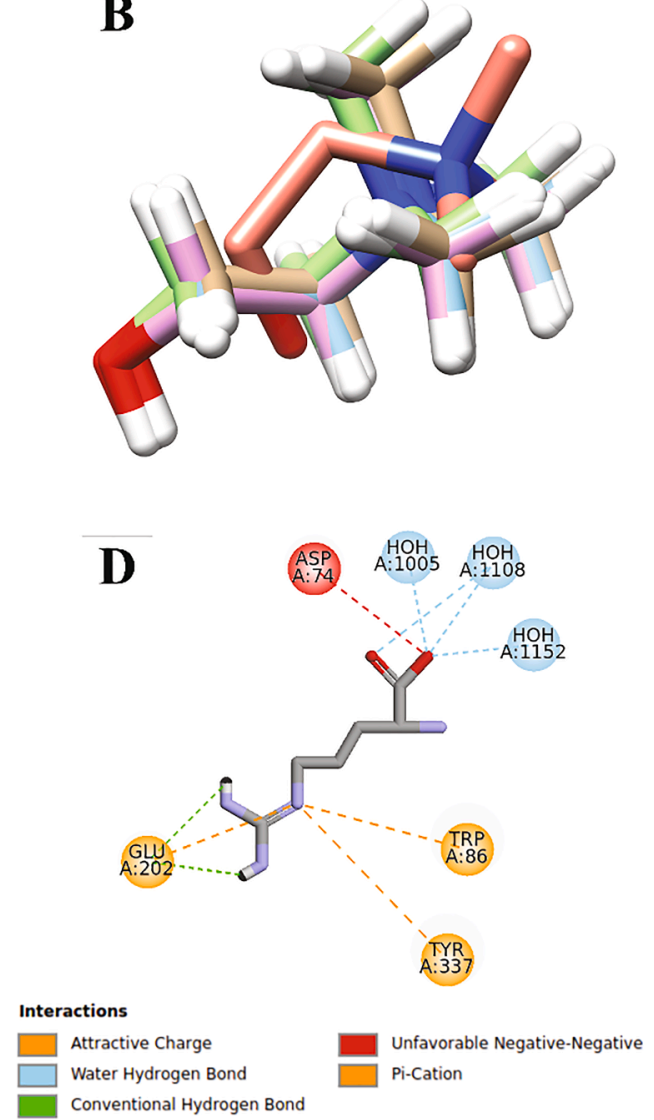

Fig. 4. Overlap the best poses obtained with choline redocking using the protocols defined for the Autodock (A) and Gold (B) programs. In pink, the pose of the crystallographic ligand, the others are the best poses of four simulations. (C) Arginine poses obtained with repetitions of docking simulations. The overlap of the same pose in all simulations suggests a pattern for the connection. (D) Interactions between arginine and Ache active site residues generated by the Virtual Studio program. (For interpretation of the references to colour in this figure legend, the reader is referred to the web version of this article.) reference in this study (Fig. 4, A-B).

Fig. 4 (C) shows that the L-arginine poses obtained in the simulations are very similar, indicating bond stability. L-arginine was selected as the library binder most likely to bind to AChE. This fact is corroborated by evidence from the literature that indicate positively charged amino acids as the major responsible for AChE inhibition. These positively charged amino acids that exist in the peptides of FPH probably bind to one of the active sites of AChE: the peripheral anionic site (PAS), forming a stable complex and preventing the entry of substrates into the enzyme active site (Malomo \& Aluko, 2016; Zhao et al., 2018).

L-arginine makes several charge-charge and charge-dipole interactions with residues of the active site (Fig. 4 (D)), but the interaction of carboxyl oxygen from arginine with carboxyl oxygen from the Asp74 residue draws attention because it is unfavorable (negative charge interaction with negative charge). However, it is worth remembering that the enzyme structure used in the simulations is static and there are several water molecules in the cavity of the active site of AChE and many of them close to this interaction (Fig. 4 (D)), which suggests that these water molecules can form a bond (water-mediated interaction) between the carboxyl of the arginine ligand and the carboxyl of the Asp74 residue, which would make the interaction even more stable and favorable in the real environment.

\section{Conclusions}

Enzymatic hydrolysis may interfere with the bioactive properties of fish protein hydrolysates. Different hydrolysis conditions, varying temperature, $\mathrm{pH}$ and enzyme concentration, were used according to the composite rotatable design to evaluate the interference in the bioactive property of AChE inhibition. The hydrolysis adjusted at $55{ }^{\circ} \mathrm{C}, \mathrm{pH} 7.5$ and enzyme concentration of $0.8 \%$ (Enzyme: Substrate), selected by principal component analysis, presented greater inhibition potential than the other experimental conditions. The results of the kinetic study showed that all FPH evaluated had a mixed-type inhibition of the AChE activity. The amino acid profile was similar for the hydrolysates evaluated, however, the hydrolysate with higher AChE inhibition presented greater amount of total and essential amino acids. In addition, according to molecular docking analysis, it was found that arginine is the amino acid most likely to bind to AChE, demonstrating that basic amino acids can be a key factor for this bioactivity. Finally, it is expected as future perspectives that these FPH could be applied in functional food formulations and pharmaceutical products as AChE inhibitors.

\section{CRediT authorship contribution statement}

Thaysa Fernandes Moya Moreira: Investigation, Formal analysis, Writing - original draft, Resources. Luiz Gustavo Antunes Pessoa: Investigation, Writing - original draft. Flavio Augusto Vicente Seixas: Investigation, Writing - original draft. Rafael Porto Ineu: Methodology, Formal analysis, Supervision, Writing - review \& editing. Odinei Hess Gonçalves: Formal analysis, Writing - original draft, Supervision. Fernanda Vitória Leimann: Conceptualization, Resources, Writing review \& editing, Supervision, Project administration, Funding acquisition. Ricardo Pereira Ribeiro: Conceptualization, Resources, Writing - review \& editing, Supervision, Project administration, Funding acquisition.

\section{Declaration of Competing Interest}

The authors declare that they have no known competing financial interests or personal relationships that could have appeared to influence the work reported in this paper. 


\section{Acknowledgements}

Authors thank to CNPq (Chamada Universal- MCTI/CNPq $\mathrm{N}^{\circ}$ 28/ 2018, Process 421541/2018-0) and Fundação Araucária (convênios 40/ $2016,53 / 2019$ and $039 / 2019$ ) for the financial support. This study was financed in part by the Coordenação de Aperfeiçoamento de Pessoal de Nível Superior - Brasil (CAPES) - Finance Code 001. Authors thank to Central Analítica Multiusuário da UTFPR Campo Mourão (CAMulti-CM) by the analysis.

\section{Appendix A. Supplementary data}

Supplementary data to this article can be found online at https://doi. org/10.1016/j.foodchem.2021.130728.

\section{References}

Ahn, C. B., Cho, Y. S., \& Je, J. Y. (2015). Purification and anti-inflammatory action of tripeptide from salmon pectoral fin byproduct protein hydrolysate. Food Chemistry, 168, 151-156. https://doi.org/10.1016/j.foodchem.2014.05.112.

Alvares, T. S., Conte-Junior, C. A., Pierucci, A. P., de Oliveira, G. V., \& Cordeiro, E. M. (2018). Acute effect of fish protein hydrolysate supplementation on vascular function in healthy individuals. Journal of Functional Foods, 46(December 2017), 250-255. https://doi.org/10.1016/j.jff.2018.04.066.

Ananey-Obiri, D., \& Tahergorabi, R. (2018). Development and Characterization of FishBased Superfoods. In Current Topics on Superfoods (Vol. 395, Issue tourism, pp. 116-124). InTech. https://doi.org/10.5772/intechopen.73588.

Association of Official Agricultural Chemists. AOAC. (2005). Official Methods of Analysis of AOAC INTERNATIONAL. In Association of Officiating Analytical Chemists (18th ed.).

Baek, H. H., \& Cadwallader, K. R. (1995). Enzymatic Hydrolysis of Crayfish Processing By-products. Journal of Food Science, 60(5), 929-935. https://doi.org/10.1111/ j.1365-2621.1995.tb06264.x.

Böcker, U., Wubshet, S. G., Lindberg, D., \& Afseth, N. K. (2017). Fourier-transform infrared spectroscopy for characterization of protein chain reductions in enzymatic reactions. The Analyst, 142(15), 2812-2818. https://doi.org/10.1039/C7AN00488E.

Boskey, A., \& Pleshkocamacho, N. (2007). FT-IR imaging of native and tissue-engineered bone and cartilage. Biomaterials, 28(15), 2465-2478. https://doi.org/10.1016/j. biomaterials.2006.11.043.

Cao, W., Zhang, C., Hong, P., \& Ji, H. (2009). Optimising the free radical scavenging activity of shrimp protein hydrolysate produced with alcalase using response surface methodology. International Journal of Food Science \& Technology, 44(8), 1602-1608. https://doi.org/10.1111/j.1365-2621.2008.01901.x.

Chalamaiah, M., Dinesh kumar, B., Hemalatha, R., \& Jyothirmayi, T. (2012). Fish protein hydrolysates: Proximate composition, amino acid composition, antioxidant activities and applications: A review. Food Chemistry, 135(4), 3020-3038. https://doi.org/ 10.1016/j.foodchem.2012.06.100.

Dallakyan, S., \& Olson, A. J. (2015). Small-Molecule Library Screening by Docking with PyRx (pp. 243-250). https://doi.org/10.1007/978-1-4939-2269-7_19.

Elavarasan, K., Shamasundar, B. A., Badii, F., \& Howell, N. (2016). Angiotensin Iconverting enzyme (ACE) inhibitory activity and structural properties of oven- and freeze-dried protein hydrolysate from fresh water fish (Cirrhinus mrigala). Food Chemistry, 206, 210-216. https://doi.org/10.1016/j.foodchem.2016.03.047.

Ellman, G. L., Courtney, K. D., Andres, V., \& Featherstone, R. M. (1961). A New and rapid colorimetric determination of Acetylcholinesterase activity. Biochemical Pharmacology, 7(2), 88-95.

FAO. Food and Agriculture Organization. (2016). El estado mundial de la pesca y la acuicultura 2016. In Contribución a la seguridad alimentaria y la nutrición para todos. Roma.

FAO. Food and Agriculture Organization. (2020). GLOBEFISH Highlights January 2020 ISSUE, with Jan. - Sep. 2019 Statistics. FAO https://doi.org/10.4060/ca7968en.

Gao, R., Yu, Q., Shen, Y., Chu, Q., Chen, G.e., Fen, S., ... Sun, Q. (2021). Production, bioactive properties, and potential applications of fish protein hydrolysates: Developments and challenges. Trends in Food Science \& Technology, 110, 687-699. https://doi.org/10.1016/j.tifs.2021.02.031.

Glassford, S. E., Byrne, B., \& Kazarian, S. G. (2013). Recent applications of ATR FTIR spectroscopy and imaging to proteins. Biochimica et Biophysica Acta (BBA) - Protein and Proteomics, 1834(12), 2849-2858. https://doi.org/10.1016/j. bbapap.2013.07.015.

Grella Miranda, C., dos Santos, P. D. F., do Prado Silva, J. T., Vitória Leimann, F., Ferreira Borges, B., Miguel Abreu, R., Porto Ineu, R., \& Hess Gonçalves, O. (2020). Influence of nanoencapsulated lutein on acetylcholinesterase activity: In vitro determination, kinetic parameters, and in silico docking simulations. Food Chemistry, 307(March 2019), 125523. https://doi.org/10.1016/j.foodchem.2019.125523.

Hagen, S. R., Frost, B., \& Augustin, J. (1989). Precolumn phenylisothiocyanate derivatization and liquid chromatography of amino acids in food. Journal Association of Official Analytical Chemists, 72(6), 912-916.

Halim, N. R. A., Yusof, H. M., \& Sarbon, N. M. (2016). Functional and bioactive properties of fish protein hydolysates and peptides: A comprehensive review. Trends in Food Science \& Technology, 51(December 2017), 24-33. https://doi.org/ 10.1016/j.tifs.2016.02.007.
Hemker, A. K., Nguyen, L. T., Karwe, M., \& Salvi, D. (2020). Effects of pressure-assisted enzymatic hydrolysis on functional and bioactive properties of tilapia (Oreochromis niloticus) by-product protein hydrolysates. LWT, 122(December 2019), 109003. https://doi.org/10.1016/j.lwt.2019.109003.

Hoyle, N. T., \& MERRLTT, J. H. (1994). Quality of Fish Protein Hydrolysates from Herring (Clupea harengus). Journal of Food Science, 59(1), 76-79. https://doi.org/ 10.1111/j.1365-2621.1994.tb06901.x.

Jones, G., Willett, P., Glen, R. C., Leach, A. R., \& Taylor, R. (1997). Development and validation of a genetic algorithm for flexible docking 1 1Edited by F.E. Cohen. Journal of Molecular Biology, 267(3), 727-748. https://doi.org/10.1006/ jmbi.1996.0897.

Lima, K. O., da Costa de Quadros, C., Rocha, M.d., Jocelino Gomes de Lacerda, J. T., Juliano, M. A., Dias, M., ... Prentice, C. (2019). Bioactivity and bioaccessibility of protein hydrolyzates from industrial byproducts of Stripped weakfish (Cynoscion guatucupa). LWT, 111, 408-413. https://doi.org/10.1016/j.lwt.2019.05.043.

Lowry, O., Rosebrough, N., Farr, A. L., \& Randall, R. J. (1951). Protein measurement with the Folin phenol reagent. J. Biol. Chem., 193(1), 265-275.

Malomo, S. A., \& Aluko, R. E. (2016). In Vitro Acetylcholinesterase-Inhibitory Properties of Enzymatic Hemp Seed Protein Hydrolysates. Journal of the American Oil Chemists' Society, 93(3), 411-420. https://doi.org/10.1007/s11746-015-2779-0.

Malomo, S. A., \& Aluko, R. E. (2019). Kinetics of acetylcholinesterase inhibition by hemp seed protein-derived peptides. Journal of Food Biochemistry, 43(7), 1-10. https://doi. org/10.1111/jfbc.12897.

Mohammad, A. W., Kumar, A. G., \& Basha, R. K. (2015). Optimization of enzymatic hydrolysis of tilapia (Oreochromis Spp.) scale gelatine. International Aquatic Research, 7(1), 27-39, https://doi.org/10.1007/s40071-014-0090-6.

Morris, G. M., Huey, R., Lindstrom, W., Sanner, M. F., Belew, R. K., Goodsell, D. S., \& Olson, A. J. (2009). AutoDock4 and AutoDockTools4: Automated docking with selective receptor flexibility. Journal of Computational Chemistry, 30(16), 2785-2791. https://doi.org/10.1002/jcc.v30:1610.1002/jcc. 21256.

Naik, A. S., Mora, L., \& Hayes, M. (2020). Characterisation of Seasonal Mytilus edulis ByProducts and Generation of Bioactive Hydrolysates. Applied Sciences, 10(19), 6892. https://doi.org/10.3390/app10196892.

Nasir, S. N. A. M., \& Sarbon, N. M. (2019). Angiotensin converting enzyme (ACE), antioxidant activity and functional properties of shortfin scad (Decapterus macrosoma) muscle protein hydrolysate at different molecular weight variations. Biocatalysis and Agricultural Biotechnology, 20(July), Article 101254. https://doi.org/ 10.1016/j.bcab.2019.101254.

Nawaz, A., Li, E., Irshad, S., HHM, H., Liu, J., Shahbaz, H. M., ... Regenstein, J. M. (2020). Improved effect of autoclave processing on size reduction, chemical structure, nutritional, mechanical and in vitro digestibility properties of fish bone powder. Advanced Powder Technology, 31(6), 2513-2520. https://doi.org/10.1016/. apt.2020.04.015.

Noman, A., Ali, A. H., AL-Bukhaiti, W. Q., Mahdi, A. A., \& Xia, W. (2020). Structural and physicochemical characteristics of lyophilized Chinese sturgeon protein hydrolysates prepared by using two different enzymes. Journal of Food Science, 85(10), 3313-3322. https://doi.org/10.1111/jfds.v85.1010.1111/1750-3841.15345.

Pal, A., Paul, S., Choudhury, A. R., Balla, V. K., Das, M., \& Sinha, A. (2017). Synthesis of hydroxyapatite from Lates calcarifer fish bone for biomedical applications. Materials Letters, 203, 89-92. https://doi.org/10.1016/j.matlet.2017.05.103.

Prasasty, V., Radifar, M., \& Istyastono, E. (2018). Natural Peptides in Drug Discovery Targeting Acetylcholinesterase. Molecules, 23(9), 2344. https://doi.org/10.3390/ molecules23092344.

Rajabzadeh, M., Pourashouri, P., Shabanpour, B., \& Alishahi, A. (2017). Amino aci composition, antioxidant and functional properties of protein hydrolysates from the roe of rainbow trout (Oncorhynchus mykiss). https://doi.org/10.1111/ijfs.13587.

Roslan, J., Yunos, K. F. M., Abdullah, N., \& Kamal, S. M. M. (2014). Characterization of Fish Protein Hydrolysate from Tilapia (Oreochromis Niloticus) by-Product. Agriculture and Agricultural Science Procedia, 2, 312-319. https://doi.org/10.1016/j. aaspro.2014.11.044.

Silva, J. F. X., Ribeiro, K., Silva, J. F., Cahú, T. B., \& Bezerra, R. S. (2014). Utilization of tilapia processing waste for the production of fish protein hydrolysate. Animal Feed Science and Technology, 196, 96-106. https://doi.org/10.1016/j. anifeedsci.2014.06.010.

Su, G., Zhao, T., Zhao, Y., Sun-Waterhouse, D., Qiu, C., Huang, P., \& Zhao, M. (2016). Effect of anchovy (Coilia mystus) protein hydrolysate and its Maillard reaction product on combating memory-impairment in mice. Food Research International, 82, 112-120. https://doi.org/10.1016/j.foodres.2016.01.022.

Tan, E. C. K., Johnell, K., Garcia-Ptacek, S., Haaksma, M. L., Fastbom, J., Bell, J. S., \& Eriksdotter, M. (2018). Acetylcholinesterase inhibitors and risk of stroke and death in people with dementia. Alzheimer's \& Dementia, 14(7), 944-951. https://doi.org/ $10.1016 / \mathrm{j}$.jalz.2018.02.011.

Vázquez, J. A., Rodríguez-Amado, I., Sotelo, C. G., Sanz, N., Pérez-Martín, R. I., \& Valcárcel, J. (2020). Production, Characterization, and Bioactivity of Fish Protein Hydrolysates from Aquaculture Turbot (Scophthalmus maximus) Wastes. Biomolecules, 10(2), 310. https://doi.org/10.3390/biom10020310.

Ventura, A. L. M., Abreu, P. A., Freitas, R. C. C., Sathler, P. C., Loureiro, N., \& Castro, H. C. (2010). Sistema colinérgico: revisitando receptores, regulação e a relação com a doença de Alzheimer, esquizofrenia, epilepsia e tabagismo. Archives of Clinical Psychiatry (São Paulo), 37(2), 66-72. https://doi.org/10.1590/S010160832010000200007.

White, J. A., Hart, R. J., \& Fry, J. C. (1986). An evaluation of the Waters Pico-Tag system for the amino-acid analysis of food materials. Journal of Automatic Chemistry, 8(4), 170-177. https://doi.org/10.1155/S1463924686000330.

Wong, F.-C., Xiao, J., Ong, M. G. L., Pang, M.-J., Wong, S.-J., Teh, L.-K., \& Chai, T.-T. (2019). Identification and characterization of antioxidant peptides from hydrolysate 
of blue-spotted stingray and their stability against thermal, $\mathrm{pH}$ and simulated gastrointestinal digestion treatments. Food Chemistry, 271(February 2018), 614-622. https://doi.org/10.1016/j.foodchem.2018.07.206.

Yang, X., Li, Y., Li, S., Ren, X., Olayemi Oladejo, A., Lu, F., \& Ma, H. (2020). Effects and mechanism of ultrasound pretreatment of protein on the Maillard reaction of protein-hydrolysate from grass carp (Ctenopharyngodon idella). Ultrasonics Sonochemistry, 64(November 2019), 104964. https://doi.org/10.1016/j. ultsonch.2020.104964.

Zent, I., Göksu, A. G., Cakır, B., \& Gülseren, İ. (2021). Linking collective in vitro to individual in silico peptide bioactivity through mass spectrometry (LC-Q-TOF/MS) based sequence identification: The case of black cumin protein hydrolysates. Journal of Food Measurement and Characterization, 15(1), 664-674. https://doi.org/10.1007/ s11694-020-00666-Z.

Zhao, T., Xu, J., Zhao, H., Jiang, W., Guo, X., Zhao, M., ... Su, G. (2017). Antioxidant and anti-acetylcholinesterase activities of anchovy (Coilia mystus) protein hydrolysates and their memory-improving effects on scopolamine-induced amnesia mice. International Journal of Food Science \& Technology, 52(2), 504-510. https://doi.org/ 10.1111/ijfs.13306.

Zhao, T., Zhang, Q., Wang, S., Qiu, C., Liu, Y., Su, G., \& Zhao, M. (2018). Effects of Maillard reaction on bioactivities promotion of anchovy protein hydrolysate: The key role of MRPs and newly formed peptides with basic and aromatic amino acids. LWT, 97(March), 245-253. https://doi.org/10.1016/j.lwt.2018.06.051. 